\title{
AIDS-related lymphoma at the University of calabar teaching hospital (Nigeria): a seven year review
}

\author{
Marcus A Inyama 1*, IA Ibanga', Godwin Ebughe ${ }^{2}$, I Bassey², Ima-Obong Ekanem², ME Asuquo ${ }^{3}$ \\ From 13th International Conference on Malignancies in AIDS and Other Acquired Immunodeficiencies \\ (ICMAOI) \\ Bethesda, MD, USA. 7-8 November 2011
}

\section{Background}

With the use of HAART and effective treatment, prolongation of life of persons living with HIV, there has been a steady increase in cases of AIDS-related lymphoma (ARL). The number keeps increasing. The complexity of managing patients with ARL in a resource limited setting needs to be evaluated in view of the diagnostic and managerial challenges.

\section{Objectives}

To determine the prevalence of ARL in our hospital. To evaluate the outcome of patients management.

\section{Subjects and methods}

Hospital records of patients with tissue diagnosis of lymphoma from January 2005-June 2011 were examined. Those with retroviral positive results were further followed up to treatment centre at the Presidential Emergency Programme for AIDS Relief (PEPFAR) clinic. Records were also reviewed at the Calabar Cancer Registry.

\section{Results}

Fifty-four patients with lymphoma were seen within the period (2005-2011).Non-Hodgkin's lymphoma (NHL) was the most frequent 35(63\%) Hodgkin's lymphoma (HL) 8(18.2\%), Burkitt's lymphoma(BL) 7(15.9\%) and nasopharyngeal lymphoma(NL) 1(2.3\%). ARL was $12(18.2 \%)$ with NHL, HL, and NL contributing 9(62\%), 2(25\%), 1(12.5\%) respectively. Mortality was significantly higher in the ARL than in the non-ARL group.

\footnotetext{
* Correspondence: drinyama@yahoo.com

'Department of Haematology and Blood Transfusion, University of Calabar Teaching Hospital, Calabar, Nigeria

Full list of author information is available at the end of the article
}

\section{Conclusions}

ARL is not a rarity in our environment. A survey of all the HIV treatment centres will reveal a larger statistics. A greater understanding of the biology of this complex is needed. Training of all care providers to effectively manage the disease is highly recommended. The cost of drugs for the treatment of the lymphoma is prohibitive to most of the indigent patients who present to our centre.

\section{Author details}

${ }^{1}$ Department of Haematology and Blood Transfusion, University of Calabar Teaching Hospital, Calabar, Nigeria. ${ }^{2}$ Department of Pathology, University of Calabar Teaching Hospital, Calabar, Nigeria. ${ }^{3}$ Department of Surgery,

University of Calabar Teaching Hospital, Calabar, Nigeria.

Published: 19 April 2012

doi:10.1186/1750-9378-7-S1-P1

Cite this article as: Inyama et al: AIDS-related lymphoma at the

University of calabar teaching hospital (Nigeria): a seven year review.

Infectious Agents and Cancer 2012 7(Suppl 1):P1.

Submit your next manuscript to BioMed Central and take full advantage of:

- Convenient online submission

- Thorough peer review

- No space constraints or color figure charges

- Immediate publication on acceptance

- Inclusion in PubMed, CAS, Scopus and Google Scholar

- Research which is freely available for redistribution

\section{() Biomed Central}

